\title{
Earth's green heroes
}

\author{
Eating the Sun: How Plants Power the \\ Planet \\ by Oliver Morton ${ }^{\star}$ \\ Fourth Estate: 2007.384 pp. $€ 25$
}

\section{Richard Fortey}

All the greatest monsters are green. The Incredible Hulk had to turn green before going on the rampage and the Eagle comic featured a supremely evil green being called the Mekon, who was opposed in almost every issue by the chisel-jawed space hero, Dan Dare. One explanation for this odd association of colour with character is that green belongs to the vegetable kingdom. Humanoids have no right to have chloroplasts in their tissues - and if they do have them, well, they are probably not quite right. In the plant world, green is a heroic tint. It's a measure of the presence of chlorophyll and a sign that an organism captures energy from the Sun to convert it into organic matter. This is the basis of almost all life on the planet, and is arguably the single most important biochemical pathway there is.

Oliver Morton has written a biography of this organic greenery. He takes us on a grand tour from molecules to biosphere, and a very impressive journey it is. He tackles the difficulties of explaining how photosynthesis works, and teases out the exciting story of how electrons hop from one molecule to another along their complex pathways. If you thought that photosynthesis simply 'splits' carbon dioxide into its constituent elements in order to build organic molecules and release oxygen, you will soon be disabused. The oxygen is derived from water molecules, as part of the elaborate atomic trade-offs that power cells.

These complexities might have benefited from a few more diagrams to help the less biochemically literate, although to the uninitiated, looking at folded proteins can be as confusing as contemplating a plate of tagliatelle. And Morton's writing is exemplary in its clarity, drawing an analogy where it will help, and grasping conceptual nettles where it won't.

Morton goes on to outline the 3.5-billionyear-plus history of photosynthesis on Earth. It is by now a familiar fact that we owe our oxygenated atmosphere to the early and relentless activity of photosynthetic cyanobacteria and, subsequently, of algae. These small organisms converted the seas into something that could be colonized by respiring animals by harnessing the Sun's energy over three-quarters of geological time. There is simply no escaping a kind of modified Gaia outlook here: life, nutrient cycles and rock weathering are all locked together in one inescapable dance.

Less familiar to most readers will be some of the crucial episodes during this long history. There were times when Earth is thought to

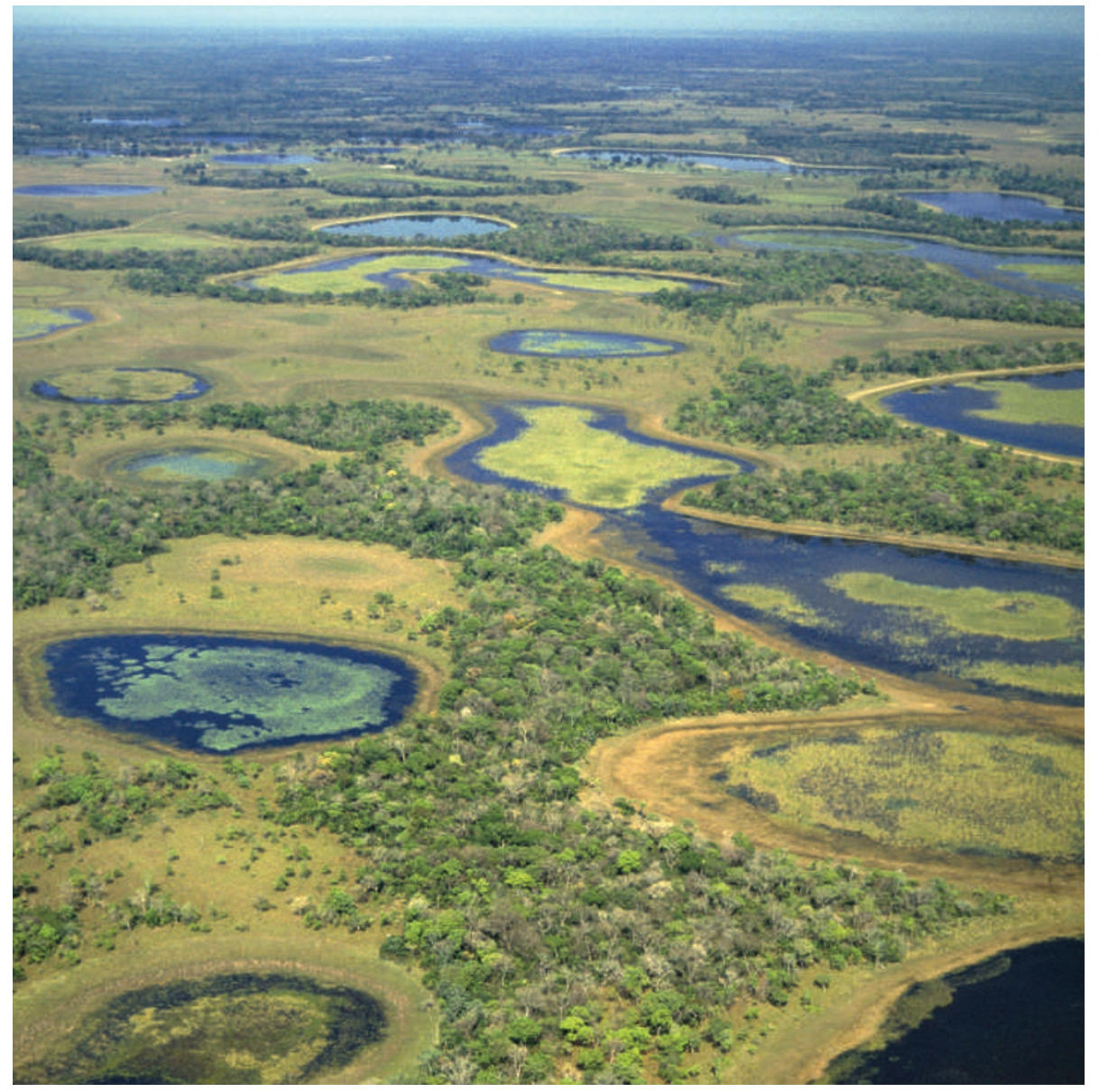

The ability of green plants to harness the Sun's energy is the basis of almost all life on Earth.

have almost completely frozen over, for example. The Precambrian was not one slow story of advance towards the emergence of animal life. During the mid-Proterozoic, there was a period dubbed the 'boring billion' when nothing much happened in the way of biological innovation, at least according to many palaeontologists - life simply ticked over. It is not certain whether this stasis was linked to a shortage of available nitrogen or to the absence of animals to provide a fillip to innovation.

Whatever the reason, when animals did appear after about 1 billion years ago, the pace of evolution sped up dramatically. Morton is very good on what is needed to turn an alga into a land plant, and then to prop up that plant so that it can bathe in air and light to make a tree. The greening of the ancient continents was the final triumph of the chloroplast.

Eating the Sun proceeds smoothly to an account of climate history. Plants have influenced, and been gripped by, climatic fluctuations that have produced alternations of a 'greenhouse' and an 'icehouse' world. The climatic changes that seem inevitable to us now have, in all likelihood, been paralleled at one time or another in geological history. What is unprecedented is the burning of so much photosynthetically fixed carbon that had been sealed away in rocks. What time had sequestered so securely is now being blasted into the atmosphere by thousands of power stations.

The book describes with admirable dispassion the different hypotheses detailing how the biological and human world might cope with this challenge. It is good to have a proper acknowledgement of the difficulties of predictive climate modelling, where there are so many unknowns - particularly in biotic responses to increased carbon dioxide availability. Theoretical mitigation possibilities — such as seeding some parts of the ocean with iron to stimulate plankton blooms - are carefully considered and then given short shrift. The problem is that we cannot simply wait around for the science to improve just so that we might better appreciate the particular flavour of our doom. Unfortunately, quite a few of the precautions that should have been taken against this have already been surpassed.

If we want to see just how bad things might become, we can contemplate the dreadful object lesson of the biological world after the mass extinction at the end of the Permian period, when a sick and enfeebled biosphere took millions of years to recover - indeed, 
nothing as bad followed even the extinction of the dinosaurs. Morton briefly reviews the alternative sources for the energy consumption to which humankind is so addicted. The problem with such sensible words is that the reader still feels that no rational course will ever be adopted until the very tragedies that we seek to avert have come to pass. Of several recent accounts of what might happen to climate in the next decades, Morton's is among the most balanced, but I am still left crossing my fingers and recycling a few plastic bags. As T. S. Eliot remarked, humankind cannot bear very much reality.

Morton's account of the ubiquitous importance of photosynthesis is an original viewpoint for looking at the world. It is written with verve and an eye for detail. His breadth of scholarship could leave other science writers green - with envy.

Richard Fortey is visiting professor of palaeobiology at Oxford University, and research associate at the Natural History Museum,

Cromwell Road, London SW7 5BD, UK.

*Oliver Morton is Nature's chief News and Features editor.

\section{Science and the Supreme Court}

\section{The Nine: Inside the Secret World of the \\ Supreme Court \\ by Jeffrey Toobin \\ Doubleday: 2007.384 pp. $\$ 27.95$}

\section{Henry T. Greely}

The United States Supreme Court is one of the more unusual aspects of a very unusual country. An unelected body that is expressly nonpolitical, its membership is subject to bitter political struggles and its decisions can have profound political consequences - sometimes even changing history. Its nine members are famous but faceless, oddly

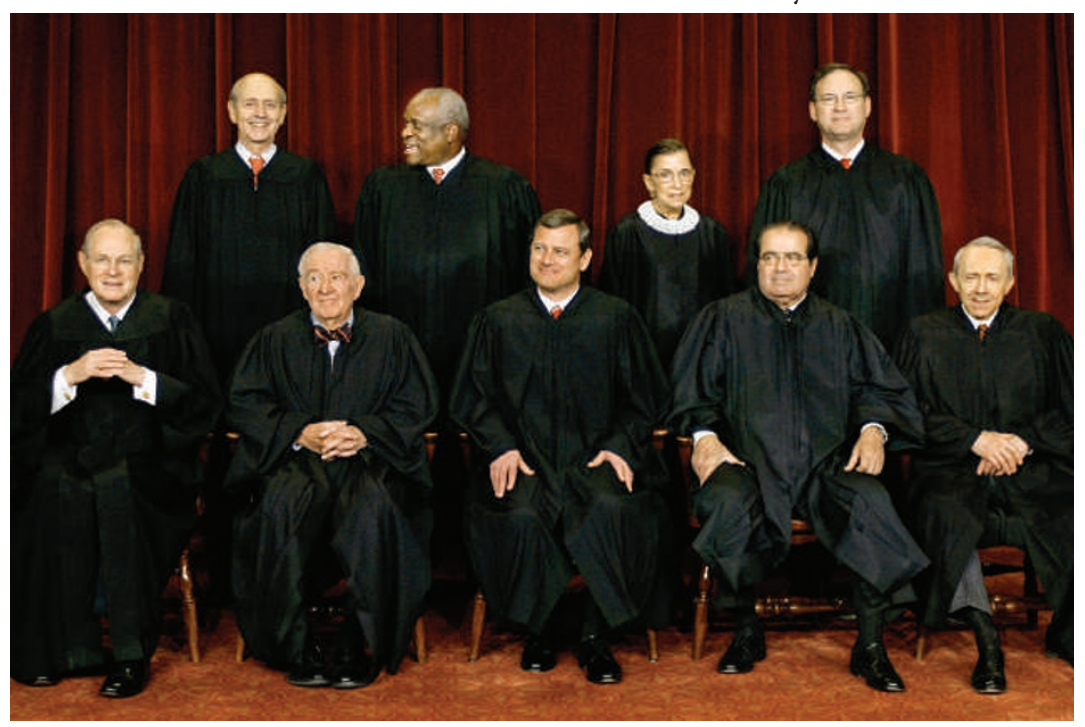

George W. Bush nominated two of the current nine Supreme Court judges. justices (and their law clerks) are intelligent, hard-working and dedicated, weighing and reweighing every word. Technically, 30 years ago and today, the justices usually do an excellent job, but their different perspectives often lead to different decisions. The book shows that these views are complex and can be only poorly summarized as 'conservative' or 'liberal'; the effects of those views are also complicated.

In ways that non-lawyers do not always understand, the Supreme Court is the weakest part of the US government. It has no power over the laws of the 50 states unless those laws run foul of the regulations, statutes or Constitution of the federal government. It cannot overturn actions by Congress unless they violate the Constitution, or of the president unless they ing yet another claim that a prisoner's attorney was incompetent, or writing and rewriting another background paragraph for a case that will attract no attention. In some ways, tices spend most of their working lives readmatic aspects. Many of the cases have no liberal or conservative side, which may help to explain why even the deeply divided court of unanimously.

Just as science clocks up more drudgery than 'Eureka!' moments, Supreme Court jus- although he overemphasizes the influence

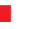
impersonal in the midst of a culture of celebrity. These nine people work painstakingly at a difficult job that is usually routine and often obscure.

Jeffrey Toobin is a staff writer at The New Yorker and a legal analyst for $\mathrm{CNN}$. His latest, very readable book is one of several efforts in the past few decades to personalize the Supreme Court and its members. He does so through a close examination of the past 20 years of its membership and decisions. The inside stories of the famous cases he discusses are not shocking, they are intriguing violate the Constitution or statutes. Even when such issues arise, the court is forced to be responsive, not active. Justices who want to decide an important issue have to wait for it to be argued in a real case that reaches them through a chain of lower courts. Then they have to hope that they can persuade at least four colleagues to agree with them, on both the result and the reasoning.

Still, the Supreme Court has plenty of power and that power will sometimes involve science. It applies patent and copyright laws in ways that affect high-tech industries and - particularly the discussion of Bush vs Gore, which prematurely ended Al Gore's challenge to George W. Bush's 2000 election. The book's strength, though, is not its account of the court's history, but what it reveals about the men and women who wear the robes. It is enlightened and enlivened by insights gleaned from Toobin's many interviews. Toobin focuses particularly on the rise to prominence of Justice Sandra Day O'Connor and the likely conservative future of the Supreme Court after her 2006 retirement.

Nearly 30 years ago, I had the good luck, and honour, to serve as a law clerk for a justice of the Supreme Court. Toobin's portrayal of the court generally feels right to me, a justice's work resembles a scientist's. Both examine lots of inputs - laws, precedents and arguments for the justice; data and hypotheses for the scientist. And they try to make sense of them, to find a solution that will work. Both know they will have to defend their solution by the authority of their positions and by their reasoning. Scientists' papers are scrutinized for any weaknesses by friends and rivals; justices face external and internal critics, sometimes being the targets of stinging dissent from their colleagues on the Supreme Court

In most cases, no verifiable (or falsifiable) truth underlies the Supreme Court's decisions. As Toobin illustrates nicely, every justice has a different view of the law, and the world. The universities. It can interpret the First Amendment to judge attempts to limit the teaching of evolution. It can decide what kind of scientific evidence a court can admit. But most of what is important to 'science' itself is not within the Supreme Court's jurisdiction. For example, President Bush's restrictive stem-cell funding policy or California's expansive policy could come before the court only on claims that they violated the Constitution, but no such claim is plausible. The Supreme Court will not rule on whether human actions are changing the climate: at most, it might decide whether state regulation of industries to limit climate change interferes with powers reserved to the federal government. 